\title{
FORMING OF THE LOGICAL SKILLS WITH THE HELP OF THE SAMPLES OF FANTASY FICTION
}

\author{
OXANA KHALABUZAR, \\ Candidate of Pedagogical Sciences, \\ Associate Professor \\ https://orcid.org/0000-0003-2338-0854 \\ ОКСАНА ХАЛАБУЗАР, \\ кандидат педагогічних наук, \\ доцент \\ oxa-khalabuzar@ukr.net \\ Berdiansk State Pedagogical \\ University \\ $\triangle 4$ Schmidta St., \\ Berdiansk, Zaporozhye region, 71100 \\ Бердянський державний \\ педагогічний \\ $\triangle$ вул. Шмідта, 4, \\ м. Бердянськ, Запорізька обл., \\ 71100
}

Original manuscript received: August 17, 2019

Revised manuscript accepted: September 12, 2019

\begin{abstract}
The article is devoted to the peculiarities of the process of formation of logical skills of students of pedagogical higher educational institutions on the material of works of art. The logical knowledge and skills that can be improved through pre-designed tasks with logical load are outlined. The author states that the conscious mastering logical skills helps to develop the creative thinking, to develop the argumentation of the teacher, to increase the productivity and effectiveness of the pedagogical activity during the work with the samples of the texts.

Within modern conditions of the transformation our national education according to the norm of the European educational environment, we deal with the problem of the training of the future specialist which would be able to compete at high professional level. This teacher has to be mobile, creative and logical. Future specialist has to analyze the given material, to maintain the connections which appear among the phenomena, to implement logical knowledge.

Logical skills give students the needed opportunity to think critically, to state the connection between thoughts and samples of the given information, to prove the truth. Also it should me mentioned the importance of the choice and implementation of the literature content which would be used for the forming of the students' logical skills within the context of the professional training. The creation of various projects, modeling problem situations for the discussions are very useful and effective. Within such condition students have opportunities to reveal their strength, to make complicated decisions and to discuss the consequences, to strengthen their own reflexive position, to analyze the results of their activity.

Favorable conditions for the formation of the culture of students' logical thinking arise in classes on literature, history, language, social science, when the teacher, sending students to certain texts, documents and facts, suggests to analyze them and ask questions, the answers to which would reveal the essence of dos leading phenomena. you can invite students to hold a "Binary Lesson", which is a continuation and development of problematic presentation of the material in the dialogue of two


lecturers. It is necessary to simulate situations of discussion of theoretical and practical issues by two "specialists", who at the end of the lecture should analyze their own activities and give them an assessment. During the work on tasks with the theoretical logical content we have made the stress on the necessity to develop logical skills during the work with the fantasy fiction's samples.

Key words: logical thinking, creative thinking, own reflexive position.

Within modern conditions of the transformation our national education according to the norm of the European educational environment, we deal with the problem of the training of the future specialist which would be able to compete at high professional level. This teacher has to be mobile, creative and logical. Future specialist has to analyze the given material, to maintain the connections which appear among the phenomena, to implement logical knowledge, logical methods and skills, to make conclusion and to argue correctly. It means that various disciplines, particularly English language lessons or English literature are able to help during the formation of the personality with the high level of the logical culture. The samples of the fantasy literature which could be considered as the romantic literature with the elements of the mysterious events, supernatural creatures and mystics, are rich in stylistic, artistic means. So, within the content of the philological training of future specialists the work with the fantasy fiction's samples gives the wide variety of opportunities for the upbringing logical culture of the linguists. Thus as the aim of our research we can state the determination of the logical skills which could be taught at linguistic disciplines with the help of the samples of the modern literature. The fantasy fiction is one of the most popular mass literature genres. Its infernal images, bright landscapes and strong characters are very interesting for the new generations. Thus many foreign researchers study the significance of the implementation of the fantasy fiction's samples during the formation of the personal qualities (E.Bjork, Y.Praice, E.Burkhead, V.Sommers, etc). Our national scientists also underline the importance of the work with the fantasy books (S.Loginova, B.Nevskiy, M.Parfenov, M.Ivanov) during the professional training of future linguists. Thus, we have to reorganize our everyday pedagogical activity for the improvement of the quality of the students' training at high educational establishments, considering modern interactive technologies.

As we know, the teacher's thinking has to be based on the basis of the logical culture which has gained the tremendous knowledge. The successful solution of the complicated tasks depends on the pedagogue, his or her personal qualities, erudition etc. The profession of the teacher demands the constant creativity and culture's improvement, constant logical thinking. [4,17]. So, the fundamentals on Logics are very important because they are necessary for the process of the choosing materials, texts' analyzing, making decisions. A.Hetmanova states that the conscious mastering logical skills helps to develop the creative thinking, to develop the argumentation of the teacher, to increase the productivity and effectiveness of the pedagogical activity during the work with the samples of the texts. During the lessons which deal with the "text work" we can explain students the existence of 
different kinds of knowledge: theoretical knowledge, knowledge-methods, knowledge-values. The theoretical knowledge provide students with the needed logical skills and operations. The knowledge-methods deal with the issues of the planning and organization of the studying activity, with the opportunities of collecting information. The knowledge-values provide the mastering norms of the professional principles, rules, professional culture of the future specialist. A. Hetmanova and I.Ivin state that all these knowledge could be formed during the work with the sample of the text. According to our point of view, the implementation of the fantasy fiction is really effective during the lessons of English lesson. The modern fantasy fiction is very important and interesting for the young people due to its creative, mysterious worlds which were created by the talented authors.

During our research we have worked with the fantasy fiction's samples from books which were written by foreign authors (R.Tolkien, J.Rowling, U.Le Guin, K.Holdstock etc) and from books, which were created by national writers (V.Arenev, M.Kidruk, N.Savchuk, D.Korniy, Y.Katorozh, etc). The conducted research proved that the logical laws, which were formulated by Aristotel, could be explained on the material of the literature lessons. Students are able to increase their ability to think rationally, to maintain the correctness and adequacy of the mental activity, to find the truth, to analyze the material.

A.Hetmanova states that the logical laws have to be taught because they help students to reflect certain connection of the subjects of the material world [4]. O.Kuzina determine the logical laws as the certain logical form which guarantees the truth of each content. During the lesson we have given students the samples of the texts with the small instruction which was presented on the interactive board.

1. Read the sample from the book "The Ash from the Dragon's Bones", written by V.Arenev.

2. State the main idea of the sample.

3. Write two arguments (for and against) on this statement.

4. Discuss these arguments with your group-mates.

5. Remember that within one statement each thought has to be clear, unchangeable and proved by strong arguments.

Students have shown their active cognitive position due to the organized educational process and given detailed instructions. During the lesson it was also underlined that the violation of the logical laws takes place when we change the subject of the discussion, when we use one term instead of the needed one without the warning for the opponents.

Logical skills give students the needed opportunity to think critically, to state the connection between thoughts and samples of the given information, to prove the truth. Also it should me mentioned the importance of the choice and implementation of the literature content which would be used for the forming of the students' logical skills within the context of the professional training. The creation of various projects, modeling problem situations for the discussions are very useful and effective. Within such condition students have opportunities to reveal their strength, to make complicated decisions and to 
discuss the consequences, to strengthen their own reflexive position, to analyze the results of their activity.

Another exercise was based on the abstract from the book "Alchemistry of Freedom" which was written by Y.Katorozh. students had to read the sample, to underline and explain the bright stylistic devices and to state the thesis, arguments and to argue with the opponent. Also they had to keep in mind that each argument has to be strong and logically proved. This task is able to develop the critical thinking, confidence and ability to lead the discussion. It teaches to work with the given information, to make the conclusion, to think critically, to state own thoughts and decisions.

Each lesson included theoretical material on the basis logical knowledge and operations which were presented due to the creation of the conditions which were appropriate to the process of forming logical thinking. Also non-standard lessons provide the positive atmosphere of the students' cooperation. For example, conversations, discussions, brain-rings and brainstorms, reports and conferences. Thus, during the work on the sample of "The Lord of the Rings", written by R.Tolkien, we suggested students to prepare the conference and small video-files which represented different aspects of the author's biography, factors which influenced on the his style. The students worked in diads, in small groups. They stated hypothesis, looked for the arguments, made questions and proved their point of view. Another form of the work - the binary lecture was used during the work on the sample from the book "The Return of the Witch" which was written by V.Klimchuk. Two students prepared the material and successfully led the lecture, involving other students with the help of the on-line materials.

Especially interesting for the students was the quest which was devoted to the creative work of modern Ukrainian authors - Marina and Sergey Dyachenko.

Due to the prepared tasks on the development of the logical skills, students increased their ability to analyze, to compare, to find the main idea and to state.

The quest based on the book "The Witch" took place out-of-doors, in the museum, park zone and art gallery. This provided the students' creativity, mobility of their logical thinking .

The organization of the class work in the auditorium also has rather significant role. Thus, on the lesson which was devoted to the work with the creative work of R.Tolkien, we have placed desks and chairs on circle, trying to represent the discussion of the main characters in the Middle Earth. It has to be mentioned that this provided the positive emotional atmosphere of the lesson. Students freely led the discussions, took part in role-playing, analyzed the samples.

Thus the actualization of the logical knowledge has to be the interactive process which is characterized by the combination of its components, by the harmony of these determined components.

There is one sample of the work with the abstract of the fantasy fiction:

1. Choose the card. 
2. Make the prediction about the sample. Imagine what will it be about.

3. Write down 2-3 sentences, using the new vocabulary.

4. Write down the small essay using the Present Simple, Present Perfect Continuous.

5. Read the sample. Translate it.

6. State the main idea and analyze it.

7. Tell if you have been in such situation. Explain your feelings and actions.

These cognitive steps obviously avoid the reproductive thinking. According to this instruction we make students to think independently, creatively and critically, to give examples from their lives, to make decisions and conclusions, to make predictions and to analyze them.

Working with different projects students have to prove, to defend their ideas and thoughts independently. This guarantee the forming of their confidence and responsibility during the time of argumentation. The students' activity has to be correct and correspondent to the main rules of the argumentation. As we know the argumentation which is directed on the proof of the certain statement, consists of thesis which has to be proved with the help of the arguments. Thus, we have to state the connection between the arguments and facts. Students have to find independently the facts which could be used as the arguments. (statements which can prove or deny).

In the process of solving the problem, students establish, discover, find out the links between the basis and judgments. The process of argumentation leads to the discovery of activity, the logic of thinking, the independence of a higher level, since the nature of activity in obtaining excerpts and substantiating knowledge is included in the system of evidence, although the facts themselves are not provided, and they should be attracted independently to obtain only the necessary arguments. Facts are the basis of arguments, and the correct use of them depends on the ability of students to see the essence of the phenomena, correctly use the derivative titles.

During the work with the fictional texts we make students to construct their arguments, to state objectives, to prove necessary facts, to show the ability to make the necessary conclusions and improve the critical attitude to the findings. The significance of learning the science of argumentation, mastering making and proving judgments during the educational process is really important. The authors of many works not only on logic, but also on the methodology of teaching certain disciplines point out that the arguments should be stated by students and by their teacher during the real interactive discussion.

Questions and tasks on mastering making arguments require the correct synthesis of actual factual material which has to be done by the speaker. There are some situations and task for the mastering skills of creating strong arguments, which could be used:

1) during the process of studying the biography of the writer to prove the significance of the writer's life and his creative way in the social-political life of the society;

2) during the process of establishing the connection of literary works 
with the social and political life of his era;

3 ) during the process of revealing the idea of the work, the features and the role of the heroes;

4) during the process of substantiating the belongings of an artistic work to a certain direction, to a certain genre;

5 ) during the process of proving of the artistic skills of the writer.

Systematic involvement of tasks with the logical knowledge in the process of forming a culture of logical thinking activates the process of assimilating logical knowledge, increases the development of students.

The highest level of cognitive activity, oriented on mastering the culture of logical thinking, is characterized by the creative activity of students, aimed at establishing and disclosing the essence of the problem, for which it is worth recognizing: a) the significance of those concepts whose essence must be established; b) to formulate a provision that needs to be substantiated (at the previous level it is given in the finished form) to select the actual material for the confirmation of the arguments (the nature of the activity, as well as in the decision of the tasks of the second level).

Favorable conditions for the formation of the culture of students' logical thinking arise in classes on literature, history, language, social science, when the teacher, sending students to certain texts, documents and facts, suggests to analyze them and ask questions, the answers to which would reveal the essence of dos leading phenomena. you can invite students to hold a "Binary Lesson", which is a continuation and development of problematic presentation of the material in the dialogue of two lecturers. It is necessary to simulate situations of discussion of theoretical and practical issues by two "specialists", who at the end of the lecture should analyze their own activities and give them an assessment. The advantages of such a lecture are updating the acquired knowledge, creating a problem situation, deploying the system of proof, consolidating the ability to conduct a discussion, highlight the main thing, generalize

Conclusion. During the work on tasks with the theoretical logical content we have made the stress on the necessity to develop logical skills during the work with the fantasy fiction's samples.

\section{References}

1. Gershunskiy B.S. Pedagogicheskaya prognostika: Metodologiya, teorlya, praktika / B.S. Gershunskiy. - K.: Vyisshaya shkola, 1986. - 200s.

2. Grinova V.M. Formuvannya pedagoglchnoYi kulturi maybutnogo vchitelya (teoretichniy ta metodichniy aspekti) / V.M. Grinova. - H.: Osnova, 1998. - 300s.

3. Prokopchuk V.E. Metodichna pldgotovka u profeslynly osvitl maybutnlh vchitellv / V.E. Prokopchuk // Pedagoglka I psihologlya. - 1996. - \# 2. - S. 136-140.

4. Semichenko V.A. Psihologlya pedagoglchnoYi dlyalnostl: navchalniy poslbnik [dlya VNZ] / V.A. Semichechenko. - K.: Vischa shkola, 2004. - 335s.

\section{Література}

1. Гершунский Б.С. Педагогическая прогностика: Методология, теорія, практика / Б.С. Гершунский. - К.: Высшая школа, 1986. - 200с. 
2. Гриньова В.М. Формування педагогічної культури майбутнього вчителя (теоретичний та методичний аспекти) / В.М. Гриньова. - Х.: Основа, 1998. - 300с.

3. Прокопчук В.Є. Методична підготовка у професійній освіті майбутніх вчителів / В.Є. Прокопчук // Педагогіка і психологія. - 1996. - № 2. - С. 136-140.

4. Семиченко В.А. Психологія педагогічної діяльності: навчальний посібник [для ВН3] / В.А. Семичеченко. - К.: Вища школа, 2004. - 335с.

\section{АНОТАЦІЯ}

Стаття присвячена особливостям процесу формування логічних навичок студентів педагогічних вищих навчальних закладів на матеріалі художніх творів літератури. Окреслено логічні знання та навички, які можна поліпшити за допомогою заздалегідь розроблених завдань із логічним навантаженням. Автор стверджує, що свідоме засвоєння логічних навичок допомагає розвивати творче мислення, розвивати аргументацію вчителя, підвищувати продуктивність і ефективність педагогічної діяльності під час роботи з уривками художніх текстів.

У сучасних умовах трансорормації нашої національної освіти відповідно до європейського освітнього середовища ми маємо справу з проблемою майбутньої підготовки фрахівців, яка зможе конкурувати на високому професійному рівні. Цей вчитель повинен бути мобільним, творчим і логічним. Майбутній фрахівець повинен уміти проаналізувати наданий матеріал, зберегти зв'язки, які з'являються серед явищ, реалізувати логічне знання.

Логічні навички дають студентам необхідну можливість критично мислити, констатувати зв'язок між думками, щоб довести правду. Також варто відзначити важливість вибору та реалізації літературного змісту, який би використовувався для формулювання логічних навичок студентів у контексті професійної підготовки. Створення різних проектів, моделювання проблемних ситуацій для обговорення $є$ дуже корисним і ефрективним. У такому стані у студентів є можливість виявити свої сильні сторони, приймати комплексні рішення та обговорювати наслідки, зміцнювати власну рефлексивну позицію, аналізувати результати своєї діяльності.

Сприятливі умови для фрормування культури логічного мислення студентів виникають під час занять з літератури, історії, мови, соціальних наук, коли викладач пропонує проаналізувати їх і поставити питання, відповіді на які мають розкрити сутність явищ. Ви можете запропонувати студентам провести «Бінарний урок», який є продовженням і розвитком проблематичного викладу матеріалу в діалозі двох викладачів. Необхідно моделювати ситуації обговорення теоретичних і практичних питань двома «експертами», які після закінчення лекції повинні проаналізувати власну діяльність і дати їм оцінку. Під час роботи над завданнями з логічним навантаженням ми підкреслюємо необхідність розвитку логічних навичок під час роботи з уривками франтастичної франтастики.

Безперечно, фрахова лінгвістична діяльність передбачає ціннісне ставлення до оволодіння логікою мислення, а також теоретико-практичну готовність студентів, що пов'язана з прагненням вчителя до аналізу, узагальнення, осмислення роботи, що потребує оновлення змісту завдань, їхної модернізації та застосування сучасних інфрормаційних технологій під час фрахової підготовки майбутніх лінгвістів.

Ключові слова: логічні навички, творче мислення, власна рефлексивна позиція. 